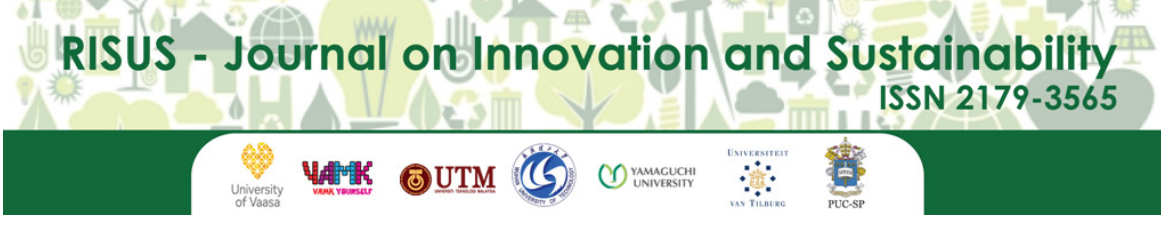

\title{
THE RELATIONSHIP BETWEEN SUSTAINABILITY PRACTICES AND INNOVATIONSTRATEGIES:THE EFFECT OF THE CLUSTERIZATION INTHE BOP SEGMENT
}

\author{
A Relação Entre Práticas Sustentáveis e Inovações Estratégicas: O Efeito da Clusterização no \\ Segmento Base de Pirâmide (BOP)
}

\author{
Sergio Luis Dias Doliveira ${ }^{1}$, Zandra Balbinot ${ }^{2}$, Adriana Queiroz Silva ${ }^{1}$, \\ João Carlos Da Cunha ${ }^{3}$, Edson Luis Kuzma ${ }^{1}$. \\ 1 Universidade Estadual do Centro Oeste do Paraná - UNICENTRO, Brasil \\ 2 École des sciences de la gestion, Université du Québec à Montréal, Canadá \\ 3 Universidade Positivo - UP, Brasil \\ E-mail: sldd@uol.com.br, balbinot.zandra@uqam.ca, aqueirozsilva@uol.com.br, \\ jccunhaisat@gmail.com, edson.kuzma@gmail.com.
}

\begin{abstract}
This manuscript describes how the perception of the importance of Clusters of Small and Medium Enterprises is increasingly evident in developing countries because they affect populations attached to the Base of the Pyramid. This force becomes fundamental when linked to organizational changes, based on the perception of sustainability in companies, which in turn influence changes in the communities at the base of the Pyramid. This research also identified and proved the influence of changes related to sustainability practices, as well as of the Innovation Strategies in the design of these transformations, in a Cluster of the garment industry in Paraná - Brazil.
\end{abstract}

Key words: Small and medium-sized enterprises, clusters, pyramid base, sustainability practices, innovation strategies

Recebido em: 03/06/2018

Aceito em: 01/09/2018 


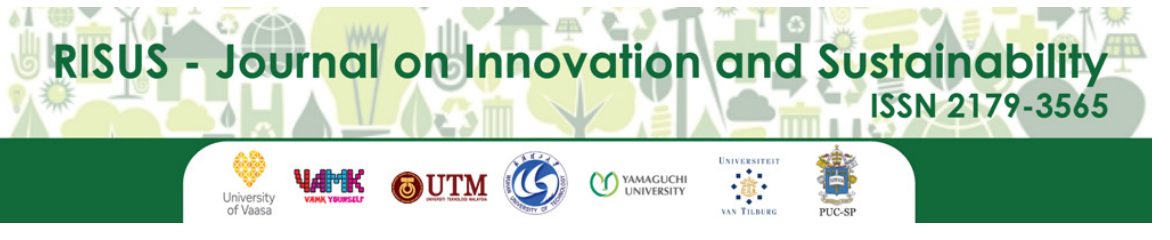

RISUS - Journal on Innovation and Sustainability volume 9, número 3 - 2018

ISSN: $2179-3565$

Editor Científico: Arnoldo José de Hoyos Guevara Editora Assistente: Lívia Lopes Aguiar Avaliação: Melhores práticas editoriais da ANPAD

\title{
THE RELATIONSHIP BETWEEN SUSTAINABILITY PRACTICES AND INNOVATION STRATEGIES: THE EFFECT OF THE CLUSTERIZA- TION IN THE BOP SEGMENT
}

\author{
A Relação Entre Práticas Sustentáveis e Inovações Estratégicas: O Efeito da Clusterização no \\ Segmento Base de Pirâmide (BOP)
}

\begin{abstract}
Sergio Luis Dias Doliveira ${ }^{1}$, Zandra Balbinot ${ }^{2}$, Adriana Queiroz Silva ${ }^{1}$, João Carlos Da Cunha ${ }^{3}$, Edson Luis Kuzma ${ }^{1}$. 1 Universidade Estadual do Centro Oeste do Paraná - UNICENTRO, Brasil 2 École des sciences de la gestion, Université du Québec à Montréal, Canadá 3 Universidade Positivo - UP, Brasil E-mail: sldd@uol.com.br, balbinot.zandra@uqam.ca, aqueirozsilva@uol.com.br, jccunhaisat@gmail.com, edson.kuzma@gmail.com.
\end{abstract}

Resumo: O presente manuscrito descreve como a percepção da importância dos Clusters de Pequenas e Médias Empresas é cada vez mais evidente em países em desenvolvimento, porque afetam populações ligadas a Base da Pirâmide. Essa força se torna fundamental quando estão ligadas a alterações organizacionais, baseadas na percepção da sustentabilidade nas empresas, que por sua vez influenciam alterações nas comunidades na base da Pirâmide. A presente pesquisa também identificou e provou a influência, de alterações ligadas às práticas de sustentabilidade, bem como, das Estratégias de inovação no delineamento dessas transformações, em um Cluster da indústria do vestuário no Paraná - Brasil.

Palavras-chave: Pequenas e médias empresas, clusters, base da pirâmide, práticas de sustentabilidade, estratégias de inovação

\author{
Recebido em: 03/06/2018
}

Aceito em: 01/09/2018 


\section{INTRODUCTION}

The organization of companies in clusters has leveraged the competitive capacity of small and midsize enterprises (SMEs) and has enabled the competitiveness of its members in the local and international market (BROWN, et all. 2001; FERNHABER, et all. 2008; CASSIOLATO, et all. 2012; CUNNINGHAM, et all.1991; FOLTA, et all. 2006). Policies for developing SMEs are becoming a priority in different emerging countries due to the need to generate employment and income for the community present at the bottom of the pyramid (BOP) (KISTRUCK, et al., 2015; SILVESTRE et al., 2014).

On the other hand, the competitive world scenario has undergone transformations that are affecting the way companies operate in the market. The large amount of information stored, as well as the exponential increase in the communication capacity of companies and individuals; the high population growth in emerging countries, among them Brazil; and changes in the planet's climate, resulting from imbalances associated with the depletion of natural resources (SACHS, 2007). All of these aspects have interfered in the context of organizational performance, in the way companies understand their relationship with society and in the leverage of environmental influence in the conduct of their business (AUTIO et all., 2014; HENDERSON, 2015).

As a result of this evolution, new concepts are being discussed, among them, the way these social transformations and new organizational relationships are affecting SMEs clusters at the BOP in emerging countries (FUNDEANU; BADELE, 2014). Likewise, innovation strategies and sustainability practices have become de facto alternatives for improving organizational development and meeting contemporary social demands within these clusters (CAMPBELL, 2007; HOPKINS, 2009a; BARBIERI et al., 2010; STEAD et al., 2008; SCANDELARI, et all. 2013; KRUGLIANSKAS, et all. 2009; AUTIO, et all. 2014). This paper proposes to verify the relationship between sustainability and innovation in the Cianorte clothing cluster and its impact on SMEs competitiveness. It should also be considered that this relationship between sustainability and innovation is not fully recognized, it is proposed here to describe it, because it is a complex concern and is not completely accepted. There are studies (HENDERSON, 2015), which place sustainability as the trigger for organizational innovations, however, there are no studies that attest this relationship, especially in Small and Medium Enterprises, inserted in clusters.

The understanding of this cluster has provided new answers, seeking to identify models of regional development that increase the performance of SMEs in clusters, especially in BOP regions (GARONE, et al.,2014). These understandings are of greater importance in a competitive scenario where innovation strategies are fundamental to the long-term survival of organizations and in which the impact of sustainability practices are regarded as essential to the organization of society (PORTER ; KRAMER, 2006; HILKE, et all. 2010; MENDONÇA et al., 2012; KNEIPP et al., 2011). According to the research, it was noticed that, regarding these initiatives, a participation of SMEs had a percentage higher than the initial expectations suggested in the literature (FERNHABER, et all., 2008; MILANEZ; OLIVEIRA, 2013).

Several studies reinforce the need to investigate the relationship between innovation and sustainable development, of which the best examples are those at the confluence of social, environmental and economic issues (GARUD et al., 2012; CARVALHO et al., 2010; PETRINI et al., 2011; HANSEN et al., 2009; MAON et al., 2010; MATHAISSEL et al., 2010). The long-term survival of organizations is directly linked to their ability to adapt and innovate in a sustainable way (BARBIERI et al., 2009; BURGELMAN et al., 2008; CASSIOLATO et al., 2005; SHRIVASTAVA, 1995; HAMEL, et all. 1995). This is a requirement, too, for SMEs, that also need to get used to this context, in which they will have better competition conditions are provided (AUTIO et al.2014; HANSEN et al., 2009; IPIRANGA, 2006; OCDE, 2007; DAVIDSSON et al., 2001). As a result, it is possible to observe that SMEs that will integrate a cluster tend to develop innovative strategies as well as sustainability practices more easily. The cluster can increase SMEs' chances of success (McCANN et all.2002; FUNDEANU; BADELE, 2014). In this sense, the Cianorte clothing cluster, in the state of Paraná, Brazil, was regarded as a field of research that brings the basic characteristics necessary to understand this phenomenon. It is a compound cluster, mainly of SMEs in the BOP.

This article is divided as follows: section 2 offers a theoretical framework and section 3 presents the 
methodological approach. The results and discussions are provided in section 4 . Finally, the investigated relationship and the final considerations are presented.

\section{THEORETICAL FRAMEWORK}

Studies of sustainability practices and innovation strategies have received greater attention, and that can be exemplified through researches that have been carried out and presented about this organizational context (AUTIO et al., 2014; SILVESTRE et al., 2014; HALL et al., 2014; KÜHL, 2012; CARVALHO, et al. 2010; PETRINI, et al. 2010).

Economic performance integrates what has come to be understood as an increment that generates social benefits (HALL et al., 2014), although there are several opinions about how only economic improvement does not necessarily imply social progress (VIZEU et al., 2012). Within this distinctive perspective, of the economic growth as a driving force for development, there is an understanding that with minimal use of environmental resources, with their recomposition, effective improvements in society as a whole also occurs (HANSEN et al., 2009; SAVITZ et al., 2007; HILKE, et all..2010). Based on the search for a new theoretical framework for the understanding of contemporary phenomena, an understanding of reality has emerged in which the perspective of sustainability practices joins the need for innovations (LÉON-SORIANO et al., 2010; BLUNDEL, et all.,2010). The study of Stoian, Rialp and Dimitratos (2016), shows that the adoption of a innovative behavior, in product or service term, in the case of those destination to the foreign market, is significantly related to the performance of this product or service in the external markets outside the company's home country, also in relation to SMEs. The comprehension that attitudes connected to sustainable development do not necessarily bring about lower economic gains also become an increasingly recognized position as rising (HENDERSON, 2015).

It was verified that studies on innovation in isolated companies and clusters also exist in high quantity (HALL et al., 2014; VALE et al., 2008; OSTER, 2010; HILKE, et all. 2010; FUNDEANU; BADELE, 2014). However, in a smaller quantity, but more and more intensively, the question of sustainability practices in the context of the organizations is analyzed, considering small and midsized enterprises (SMEs), as well as those of greater structure (AUTIO et al., 2014; MILANEZ; OLIVEIRA, 2013; PADILHA, 2009; MATHAISEL, et all. 2011; JAMALI, 2006). Based on these data and information, the objective of this study was to evaluate whether there is a relationship between sustainability practices and innovation strategies in a cluster, associated with the clothing segment, located in the city of Cianorte/PR, Brazil. The Cianorte cluster was chosen due to the preponderance of the number of small and midsized enterprises (SMEs), to their regional importance in terms of job creation in the BOP and because these industries have obtained quite satisfactory results in the clothing segment in Brazil (SINVEST, 2012).

Inside the research were investigated, tested and corroborated several hypotheses in its development, however, were selected 5 , identified as more relevant in the study:

- There is a relationship between innovation strategies and the optimization of sustainability practices in the use and development of resources to improve the organization, it presents itself in a positive and significant way;

- There is support from the Cluster, about how Innovation Strategies are configured in companies, this occurs in a positive and significant way;

- On the part of Cluster, an action that changes and enthuses the practices of sustainability that are minimizing and optimizing, in a positive and significant way.

- There is a relationship between the fulfillment of labor obligations within the social dimension of sustainability and the integration of sustainability practices into the routines of Cluster companies.

Data from the SINVEST (Portuguese acronym for Cianorte's Union of Clothing Industry Sindicato das Indústrias do Vestuário de Cianorte) also show that there are 493 companies in Cianorte and in the nearby cities within a radius of approximately $40 \mathrm{~km}$. Initial information and references of the companies were obtained from the records of the Union and Cianorte's City Hall. Through these data, it was possible to reach the companies. It is important to emphasize that the Cianorte region is the second clothing production center in Brazil (MDIC, 2012), behind São Paulo alone. 


\section{Sustainability Practices}

Despite the various debates on the subject (ELKINGTON, 1999; CARVALHO et al., 2010; BLACKBURN, 2007; GARUD, et al., 2012; SACHS, 1986; CAMPBELL, 2007; CLARO et al., 2008; DYLLICK et al., 2002), the field of study on sustainability can be considered as in development, requiring reflection and improvement in several areas. The very meaning of the term "sustainability", as well as its scope, does not have the same perception in the literature (BOS-BROUWERS, 2009; CLARO et al., 2008). For the theoretical foundation of this work, the triple bottom line concept was adopted (ELKINGTON, 1999). The use of this definition is justified by the need to study the impact of a sustainable innovation strategy in social, environmental and economic aspects.

More than ever, organizations need to respond to new demands in a sustainable way (STEAD et al., 2004). Given this, the company's strategic management provides the perspectives that guide organizations in their different levels, considering also a medium- and long-term perspective, as well as the possibilities of socio-environmental transformations (HENDERSON, 2015). For Bonn et al. (2011), sustainability strategies involve the decision-making anchored in the fundamental values, that is, in its purposes. This view of the company which, in turn, will guide the decision making process and its activities. These elementary aspects should be considered when using the concept of sustainability practices. It is reasonable to argue including, the decision making to sustainability, about everything concerning to cooperation between business partners, leads to the sharing of financial resources, technological and humans as results of the interactions inside the network (STOIAN; RIALP; DIMITRATOS, 2016), which may lead the organization to adopt a innovative behavior simply by accessing the resources and interorganizational company employees information (JOHNSON; SCHALTEGGER, 2015).

Within the perspective of transformation presented by Stead et al. (2008), the sustainability strategies are:

Integrative strategies that provide firms with competitive advantages that simultaneously enhance the quality of the ecosystem and the economic survivability of the firm. Specifically, sustainability strategies can provide cost leadership competitive advantages by focusing on such activities as reducing resource and energy use, and they can provide for product differentiation competitive advantages via reduced packaging, organic/non-toxic ingredients and so forth (STEAD et al., 2008, p. 69).

In other words, the impact of a sustainable innovation strategy is verified by the social, economic and lasting change it makes in the quality of the ecosystem surrounding it. In this perspective, as Henderson (2015) points out, the changes are a consequence of the necessary perception that resources are finite and that it is essential to create possibilities for a conception of new competitive advantages, supported by sustainable development. Therefore, the cluster environment becomes privileged to verify in a quicker and more direct way the consequences of sustainable processes (GARONE, et AL., 2015). This evaluation will be made through the understandings of the "minimization" and "optimization" of the environment (SAVITZ et al., 2007). While the minimization evaluates the reduction of the size of the organization's footprint, considering mainly the environmental, social and economic impacts of the activities developed by the company, the optimization seeks to verify if the company adopts a proactive stance in relation to the three dimensions of sustainability. Thus, with the minimization, it is sought to verify if the organization is "less harmful" (SAVITZ et al., 2007, p.153) to the environment via a posture reactive to the context of organizational performance. With optimization, the aim is to achieve a position of zeroing the environmental impacts in the exchanges with the environment and the social demands that permeate the companies, especially the SMEs that have conditions that are specific to them (FUNDEANU; BADELE, 2014; LÉON-SORIANO et al., 2010; BROWN, et al., 2001). Table 1 presents the differences between minimization and optimization. 
Table 1: Illustrating the difference between minimization and optimization

\begin{tabular}{|l|l|l|}
\hline Company Functions & Minimization & Optimization \\
\hline $\begin{array}{l}\text { Occupational safety and } \\
\text { health }\end{array}$ & $\begin{array}{l}\text { Reduces accidents in the } \\
\text { workplace }\end{array}$ & $\begin{array}{l}\text { Contributes to the health } \\
\text { and quality of life of } \\
\text { employees }\end{array}$ \\
\hline $\begin{array}{l}\text { Protection of the } \\
\text { environment }\end{array}$ & $\begin{array}{l}\text { Disposes of hazardous } \\
\text { waste }\end{array}$ & $\begin{array}{l}\text { Uses waste as input for } \\
\text { other products }\end{array}$ \\
\hline Energy Usage & $\begin{array}{l}\text { Reduces the use of solid } \\
\text { fuels }\end{array}$ & $\begin{array}{l}\text { Replaces much of the } \\
\text { current energy sources with } \\
\text { renewable ones }\end{array}$ \\
\hline Product packaging & $\begin{array}{l}\text { Reduces the use of } \\
\text { unnecessary packaging }\end{array}$ & $\begin{array}{l}\text { Develops biodegradable } \\
\text { packaging }\end{array}$ \\
\hline Customer Services & $\begin{array}{l}\text { Faster response to } \\
\text { customers }\end{array}$ & $\begin{array}{l}\text { Works with dissatisfied } \\
\text { customers in order to } \\
\text { develop more appropriate } \\
\text { products }\end{array}$ \\
\hline
\end{tabular}

Source: Adapted from Savitz et al., 2007

\section{Innovation Strategies}

Innovation is a multidimensional process, associated with the tendency to obtain knowledge that is complemented through the interaction of support mechanisms for cooperation in contexts such as those of the productive clusters (QUANDT, 2012), in which, generally, a self-governance is developed (MILANEZ; OLIVEIRA, 2013). Some common characteristics can be seen in a cluster environment with a predominance of SMEs, such as own governance, territorial proximity, productive specialization, articulation of learning and information sharing (CASSIOLATO; LASTRES, 2005). There is a perception that innovation is a process in which learning is one of the most important factors in the construction of knowledge. There are opinions, inserted in this process (HENDERSON, 2015), which point out that sustainability practices such as: preventing risk, increasing operational efficiency and selling to the environmental niche provide important innovations for organizations. It is necessary to consider knowledge as its raw material (LUNDVALL et al, 1984; KRUGLIANSKAS, et all. 2009). Thus, in the context of productive clusters, they are benefited from the dissemination and creation of knowledge that provides learning and, as a consequence, innovations occur. These phenomena are observed in the articulation of learning and information sharing (SILVESTRE et al., 2014; GÎRNEAȚ Ă, 2013). The learning process can be associated with knowledge accumulated in production activities, the so-called learning by doing. This same learning may result from the exploration of the use of a particular good or service, the so-called learning by using (OLIVEIRA et al., 2009). Within this process, one must perceive and analyze how the learning method (through interaction, use and execution of the activity) helps and contributes to the acquisition of innovations and the development of productive specialization (MILANEZ; OLIVEIRA, 2013).

An SME innovates through interactive learning processes in exchange for information with other firms present in the cluster (GASSE, et al. 1992; KRUGLIANSKAS, 1996; BLUNDEL, et al. 2010; FUNDEANU; BADELE, 2014). In this context of innovation, the accumulation of knowledge and the improvement in the procedures and abilities to design and build new products or services are related, providing an important articulation of learning (AUTIO et al., 2014). Learning by interacting (LI) derives from the company's relations with knowledge sources external to it, such as competitors, suppliers, universities, clients, providing and approaching the Open Innovation modality. Due to its territorial proximity, this development is potentialized (GARONE et al., 2015). This modality is also characterized as an innovation in which the changes are made from different experiences; contributions and situations end up complementing each other and improving products and productive processes (JENSEN et al., 2004; CHESBROUGH, 2006). 
This new know-how occurs in situations where there is learning by doing, using and interacting (DUI), that is, learning by tacit knowledge (knowledge not codifiable and difficult to transfer); it also tries to build structures and relationships that intensify and use learning by doing, by using and by interacting (OLIVEIRA et al., 2009), which are the most observed ways of developing knowledge in the emerging countries that have great potential and stimulation in the BOP (KISTRUCK et al., 2015).

Another type of innovation also important is that linked to imitative procedures. Even though they have a lesser regard in relation to the development of "new" solutions, it is also an important innovation strategy, which has fueled growth in a number of countries, especially in East Asia (HUANG et al., 2010; WAN et al., 2005). Imitative innovation is defined as the same application of an innovation or solution already produced in another organization (SANDBERG, 1999).

Another aspect of innovation strategy that should also be recognized as relevant to the research is the understanding of eco-innovation. This understanding is inserted in the perspective of how ecoinnovations are defined, with emphasis on sustainable environmental development (MAÇANEIRO, 2012). This results in a posture regarding the entire product life cycle, in reducing environmental and pollution risks, besides other negative impacts on the use of resources compared to existing alternatives (RENNINGS, 1998; ARUNDEL et al., 2009).

Eco-innovation is a part of the process in which innovation is a key factor for organizations to establish sustainability standards in the dimensions specified by regulatory agencies (FUNDEANU; BADELE, 2014). Table 2 summarizes the five main concepts of innovation strategies adopted in the study and indicates fundamental aspects to the innovation strategies adopted by the companies. In the research universe it was observed that there is a clear preponderance of imitative initiatives, DUI and $\mathrm{LI}$, in the context of SMEs.

Table 2: Synthesis of innovation strategies

\begin{tabular}{|l|l|l|l|}
\hline \multicolumn{1}{|c|}{ Conception } & \multicolumn{1}{c|}{ Authors } & \multicolumn{1}{c|}{ Mode } \\
\hline 1 & $\begin{array}{l}\text { STI (Science, } \\
\text { Technology, Innovation) }\end{array}$ & $\begin{array}{l}\text { BURGELMAN et al. } \\
(2008)\end{array}$ & Coded, formal, departmental characterization \\
\hline 2 & $\begin{array}{l}\text { DUI (Doing, Using, } \\
\text { Interacting) }\end{array}$ & JENSEN ET al., (2004) & $\begin{array}{l}\text { Tacit knowledge, leaming by doing, using and } \\
\text { interacting }\end{array}$ \\
\hline 3 & $\begin{array}{l}\text { LI (learning by } \\
\text { interacting) }\end{array}$ & CHESBROUGH, (2003) & $\begin{array}{l}\text { Interaction with diversified and extemal } \\
\text { sources to the company - Open Innovation }\end{array}$ \\
\hline 4 & Imitative Procedures & HUANG ET al., (2010) & Low-cost altemative with low risk \\
\hline 5 & Eco-innovation & $\begin{array}{l}\text { RENNINGS, (1998); } \\
\text { ARUNDEL et al., (2009) }\end{array}$ & $\begin{array}{l}\text { Firms establish sustainability standards for the } \\
\text { innovation cycle }\end{array}$ \\
\hline
\end{tabular}

It is also important to remember that traditional indicators of innovation, according to Marins and Zawislak (2010), appear as limited to capture the process of innovation that takes place inside the companies, mainly of the SMEs, in which there is a greater informality. This also indicates that the deliberate commitment of entrepreneurs with innovation initiatives is relatively smaller in organizations found in emerging economies and SMEs (HALL et al.,2014; SOPAS, 2001). However, this does not imply a lack of innovative activities, but rather in the absence of identifiers that reflect their specific ways of manifesting themselves (MARINS; ZAWISLAK, 2010). In a context where innovation strategies and sustainability practices are consolidated, it is important to consider this type of limitation.

In this discussion, another aspect to be emphasized is that there are also several situations, in which isomorphism can be identified. These findings meet the perspective developed by Dimagio and Powell (1983). In these situations, there is institutional isomorphism, which results from homogenization pressures that may be of a coercive, mimetic or normative nature. Observing these situations becomes important for the understanding of the phenomenon studied in the context of clusters in which SMEs predominate and where the BOP is stimulated (KISTRUCK, et al., 2015). 


\section{RESEARCH METHODOLOGY}

The survey was conducted in the second half of 2012 and first half of 2013. For the data collection, a mixed method (qualitative and quantitative) was used. The fieldwork occurred through semi-structured interviews that sought to elucidate in detail the operation of the cluster and its context. Important agents were interviewed in the context of the Cluster and who influenced their formation. In the other phase, as detailed below, there was a quantitative approach in the data collection that pointed out the relationship between Sustainability Practices and Innovation Strategies. This type of research configuration, according to Cresswel (2010), characterizes a mixed research.

First, the qualitative part was used to identify the characteristics of the cluster, its formation and how the process of growth and consolidation occurred. In this first phase, of an exploratory and analytical nature, primary data by means of semi-structured interviews with nine cluster-related agents and secondary data were raised. This information located the volumes and markets served, marketing channels, product quality, the type of professionals involved and characteristics in the development of design and creation of products. These are common parameters to the textile industry, as pointed out by Gîrneatã (2013). This phase was necessary to analyze, explain and criticize why the identified phenomena are occurring (COLLIS; HUSSEY, 2005; CRESWELL, 2010). The semi-structured interview script can be seen in Annex I. It should be considered that the questions were constructed based on the literature, with the observation and analysis developed, there were also suggestions from experts consulted in the pre-test of the research instrument (GRI, 2006; VELEVA, et al. 2001). Then, the data were analyzed qualitatively in an exploratory approach, in order to allow a better understanding of the topic, of context and of the cluster investigated.

The interviews were analyzed using content analysis techniques (BARDIN, 1977) and the use of the Atlas Ti software. In this first phase of the study, a data collection occurred with nine clusterrelated agents, such as representatives of Trade Unions, support entities (SEBRAE, SENAI), as well as teaching and research institutions (UEM, UNIPAR) that operate in the city of Cianorte. Table 3 below provides information on the interviews conducted.

Table 3 - People Interviewed in the Qualitative Survey

\begin{tabular}{c|l|c}
\hline Categorization & \multicolumn{1}{|c|}{ Interviewees of Entities } & Timing \\
\hline Agent 1 & APL Govemance Agent - Cianorte & $01: 05$ \\
\hline Agent 2 & SINVEST Agent - Cianorte & $01: 50$ \\
\hline Agent 3 & SENAI Representative - Cianorte & $00: 45$ \\
\hline Agent 4 & SEBRAE Representative - Cianorte / Maringá & $02: 25$ \\
\hline Agent 5 & Agent 1 of UNIPAR & $01: 45$ \\
\hline Agent 6 & Agent 2 of UNIPAR & $01: 45$ \\
\hline Agent 7 & UEM Agent & $02: 10$ \\
\hline Agent 8 & SENAI Representative - Maringá & $00: 50$ \\
\hline Agent 9 & SINDVEST Agent - Maringá & $02: 05$ \\
\hline Total & & $\mathbf{1 4 : 4 0}$ \\
\hline
\end{tabular}

Source: Field interviews

It was possible to perceive and construct, from the interviews, an understanding that the cluster is of a great importance the strengthening of SMEs. This perception, no doubt widens the perception of BOP (KISTRUCK et al.,2015).

In the second stage of the study, a cross-sectional survey was carried out, with a quantitative research being carried out (MALHOTRA, 2001; BREWER, et al. 2006) in a universe of 493 companies of the clothing industry sector in Cianorte, in the state of Paraná (SINVEST, 2013). From this universe, a nonprobabilistic sample by participation was obtained, composed of 111 companies, which accessed 
the electronic page of the research developed with the help of the Qualtrics ${ }^{\circledR}$ platform and generated questionnaires with valid answers, resulting in a sample corresponding to $22.52 \%$ of the universe, which is considered acceptable. The techniques and procedures for analyzing sustainability practices and innovation strategies were examined, interpreted and evaluated using correlation analysis methods (HAIR JR., 2005a).

A set of parametric statistical techniques was used in the analysis of quantitative data. A statistical analysis of the elements collected in the survey was done using the Statistical Package for the Social Sciences (SPSS), as well as Excel ${ }^{\circledR}$ software from Microsoft ${ }^{\circledR}$.

In order to verify the existence of a relationship between the constructs of the innovation strategies and the sustainability practices in the cluster, three procedures were performed using the statistical package SPSS ${ }^{\circledR}$, version 16.0. In the beginning, the internal consistency (reliability) of the scales employed in the measurement of the innovation strategies and the sustainability practices of the organizations investigated was verified through the Cronbach's Alpha test (HAIR et al., 2005b; MALHOTRA, 2006). From this procedure, the dispersion means and medians of each of the selected indicators were analyzed. Then, through cluster analysis, the enterprises from the sample component were categorized according to their adherence to sustainability practices in their minimization and optimization categories, giving rise to four groups. Finally, the existence of a difference in the performance of organizations in relation to innovation strategies and sustainability practices was verified according to companies' size by means of Analysis of Variance (ANOVA), followed by Tukey's post hoc test (HAIR, et al. 2005a) in order to meet the objective proposed by this study.

\section{DATA ANALYSIS AND PRESENTATION}

Characterization of the Sustainability Strategies and Sustainability Practices Constructs - qualitative analysis

The strategies based on tacit knowledge, or described in the literature review in Table 2 as DUI (Doing, Using, Interacting) are a widespread method that organizations usually value by making them into well-kept internal secrets, which is quite observed in SMEs (BROWN, et al.2001). For Feitosa et al. (2012), it is important to reflect on the dynamics of the relations and the information exchanges that occur in the clusters of companies in the BOP profile, which characterize a real articulation of learning (CASSIOLATO; SZAPIRO, 2003). In these opportunities, it is noted how important social learning is in the context of change, thus enabling innovation (PLA-BARBER, et al. 2009). The ways by which they are recognized are very specific, offering in many situations disputes over authorship or recognition of originality (SILVESTRE et al..,2014). The following excerpts from the statements of Agents 9, 4 and 5 demonstrate these facts:

There is a concern to constantly adapt to changes in scenarios and to produce and develop solutions based on the experience of good employees...

Linked to the search for information, the will to innovate and the need to compete made the companies have this attitude and positioned some companies in a more economically sustainable way. This is a little better, and there are others too that have not yet achieved stability.

It's a very big opening; it opens up a lot of different things that we don't have here. I've seen a lot of things that we have here and they don't have there. Much better even. There are companies big and small and we're not out of it. The only thing they have very strong is a matter of trends.

The discussion and considerations above point out clearly that there are pressures from the companies' operating environment, which in turn provide improvements and may also generate uncertainties, such as a heavier normalization in terms of the environment (HENDERSON, 2015). With new environmental regulations and consumer niches that seek specific characteristics of products and the production process, these situations give rise to doubts that may influence the way SMEs act and react in their working context.

Sustainability practices in their reactive and proactive categorizations provided a clearer position 
of the companies' posture in relation to this construct (FURLANETTO, et al., 2011). Evaluating the conditions of the organizations, their profiles and the activities reported by the agents, it was possible to more consistently understand the performance framework of the companies and their ways of operating within the organizational environment. When reflecting on the minimizing or reactive methods it is necessary to notice that, in the organizational universe, the companies react and act within a perspective very similar to the arguments presented by Dimagio and Powell (1983). That is, the different configurations of isomorphism are well accepted and can be easily observed in the different ways of responding to external demands. Some examples of minimizing practices that reflect the mimetic and normative isomorphism were raised, as reported by Agents 4, 5 and 6:

Also, universities contribute to information, SEBRAE and SENAI contribute strongly to this too, the union, the suppliers that we did not even mention yet. We have several suppliers. Just so you have an idea, from January to April almost 60 lectures took place. All these actions convey models that generate successes.

Because there was already, within the APL, a voluntary concern with the destination of textile waste. Nothing was thrown on the floor. I do not know if it was a culture of the entrepreneur, but it already existed, but there was no formalized action. There was this plan to compose these actions. The companies that were there should have a concern about it.

We will be able to exchange, not only involving companies, but part of the universities. This I think is very important. This approach with Italy is an action to improve the exchange of information and perhaps of experiences between companies.

The agents' feedback provides subsidies, demonstrating that most organizations comply with certain BOP standards, which are generally followed and common in countries with emerging economies, which confirms the opinion presented by Hall et al. (2014). Another aspect observed in the statements is that of "information sharing" which is a distinctive feature of clustered enterprises (GARONE, et al., 2015). It is also clear in these remarks, that much of the companies' growth is due to mimetic isomorphism (DiMAGGIO; POWELL, 1983), which can be interpreted as a form of reaction to the environment.

\section{Relationship between sustainability practices and innovation strategies}

The study evaluated the existence or not of a relation between the constructs of sustainability practices and strategies of innovation, as defined and presented previously.

The relationship between these two constructs, innovation strategies and sustainability practices, was calculated using the Pearson Correlation Coefficient (r), which is the basis for the data treatment. It is important to emphasize that the comparison between the constructs within this methodology is recommended as valid and acceptable (FIELD, 2009; HAIR JR. et al., 2005b).

It is possible to affirm that there is a positive and significant relationship between the Constructs of Sustainability Practices and Innovation Strategies $(r=0.497)$, with a determination rate in the order of $24.70 \%$, which typifies a low moderate positive correlation. This indicates that there is a possibility of simultaneous movements between the constructs. This information demonstrates that there is an approval of the arguments and studies where Oliveira et al. (2009), Bonn et al. (2011) e Stead et al. (2008) advocate the possibility of a coherent and adequate relationship between the suggested and tested constructs. Figure 1 helps to understand the confirmation of the relationship between sustainability practices and innovation strategies. 


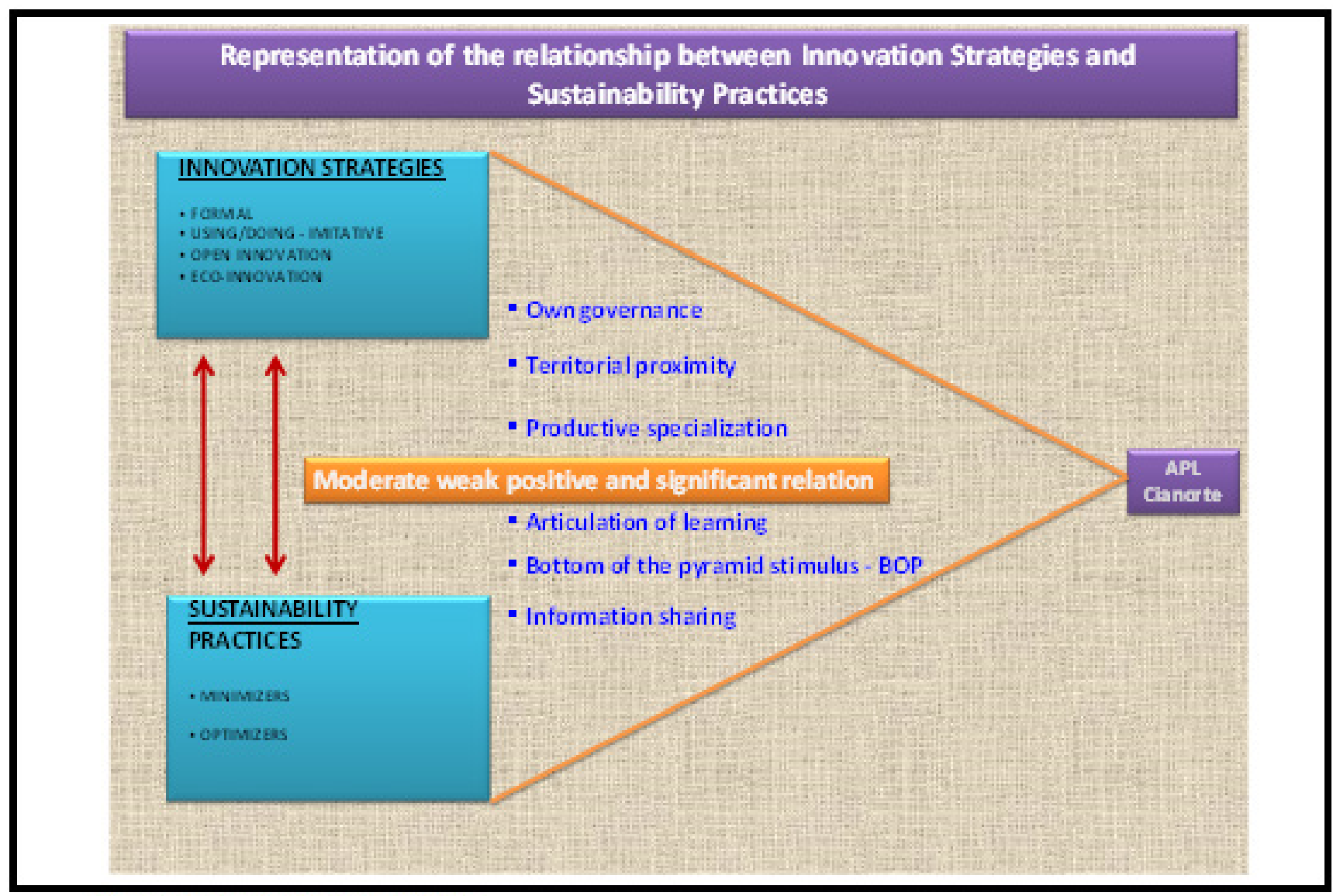

Source: made by the author

The identified relationship between the innovation strategies and the sustainability practices indicates that it will be possible to develop sets of actions that may help the companies of the Cianorte cluster. As observed by Henderson (2015), concerns about improving Sustainability often unfold in innovative initiatives. It identifies the actions directed to operational improvements, new markets, new types of clients or different sources of profit. This indicates that there will be a relationship between the constructs when looking for new development alternatives, considering and acting from the dimensions suggested by the study, pointed by the positive relationship between sustainability practices and Innovation Strategies.

\section{Internal consistency of scales, means and dispersion measures}

When the inquiry is made regarding the internal consistency (reliability) of the construct scales with interval variables, given through Cronbach's alpha coefficient, it becomes acceptable, although at a low value starting from ( $>0.6$ ) (HAIR et al. 2005, p.200). The values obtained by the scales of the innovation strategies construct $(\alpha=0.768)$ and of the sustainability practices construct $(\alpha=0.815)$, indicates that the requirements were met, denoting internal consistency of the scales. "If the correlation coefficient is strong and statistically significant, it can be concluded that there is a relationship between the variables" (HAIR JR. et al., 2005a, p. 316 - free translation).

Two complementary minimizing (reactive) and optimizing (active or proactive) categories were defined within the sustainability practices construct. In relation to Cronbach's alpha, the minimizing sustainability practices obtained $(\alpha=0.652)$ and the optimizing practices $(\alpha=0.819)$. According to information presented in table 4, the mean (M), standard deviation (SD) and coefficient of variation $(\mathrm{CV})$ were also presented, which are the measures that indicate the degree of dispersion. 
Table 4: Descriptive analysis of the Sustainability Practices Construct in its two categories

\begin{tabular}{|c|c|c|c|c|}
\hline & Minimizing Constructors Variables & Mean & SD & CV \\
\hline Var.16 & $\begin{array}{l}\text { The company is often concemed with effective practices that } \\
\text { improve the disposal of waste production. }\end{array}$ & 4.63 & 0.735 & $15.87 \%$ \\
\hline $\operatorname{Var} .17^{2}$ & $\begin{array}{l}\text { The concem to comply with the norms of environmental order is } \\
\text { permanent in the company. }\end{array}$ & 4.81 & 0.494 & $10.27 \%$ \\
\hline Var. $18^{\mathbf{a}}$ & The company acts strongly in the economy of water use. & 4.46 & 0.958 & $21.48 \%$ \\
\hline Var.19ª & $\begin{array}{l}\text { The company develops a large number of practices, which reduce } \\
\text { noise pollution in the production environment. }\end{array}$ & 4.13 & 1.189 & $28.79 \%$ \\
\hline $\operatorname{Var} 20^{2}$ & $\begin{array}{l}\text { The company practices intensely the control of electricity use in } \\
\text { its productive activities }\end{array}$ & 4.5 & 0.9 & $20.00 \%$ \\
\hline $\operatorname{Var} .21^{2}$ & $\begin{array}{l}\text { The company is heavily involved in projects for the recycling of } \\
\text { raw materials and the reuse of materials. }\end{array}$ & 3.97 & 1.423 & $35.84 \%$ \\
\hline $\operatorname{Var} .22^{\mathrm{a}}$ & All packaging used by the company is recyclable. & 3.83 & 1.273 & $33.24 \%$ \\
\hline $\operatorname{Var} .23^{2}$ & There is a strong ability to attract and retain the best talents. & 4.04 & 1.28 & $31.68 \%$ \\
\hline $\operatorname{Var} .24^{2}$ & $\begin{array}{l}\text { Employees' salaries are above the average for companies in the } \\
\text { same segment. }\end{array}$ & 2.84 & 1.291 & $45.46 \%$ \\
\hline Var. $25^{2}$ & $\begin{array}{l}\text { Concem with the local community (generation of jobs and } \\
\text { income) always has great weight in the company's decisions. }\end{array}$ & 4.15 & 1.275 & $30.72 \%$ \\
\hline $\operatorname{Var} 26^{2}$ & $\begin{array}{l}\text { Most of the company's employees file labor lawsuits when they } \\
\text { are laid off. }\end{array}$ & 1.26 & 0.596 & $47.30 \%$ \\
\hline $\operatorname{Var} .27^{\mathrm{a}}$ & $\begin{array}{l}\text { The company seeks to involve employees in the decision making } \\
\text { process that involves their areas. }\end{array}$ & 3.79 & 1.396 & $36.83 \%$ \\
\hline $\operatorname{Var} .28^{2}$ & $\begin{array}{l}\text { Unions and/or associations are involved in the decisions taken by } \\
\text { the company. }\end{array}$ & 1.88 & 1.334 & $70.96 \%$ \\
\hline \multicolumn{2}{|r|}{ Average of the Sustainability Practices Construct - Minimizers } & 3.71 & & \\
\hline & Optimizing Constructors Variables & Mean & SD & $\mathrm{CV}$ \\
\hline Var. $29 a^{2}$ & $\begin{array}{l}\text { There is regular training of employees aimed at improving } \\
\text { productivity. }\end{array}$ & 3.7 & 1.53 & $41.35 \%$ \\
\hline Var.30”. & $\begin{array}{l}\text { There are concems and actions that aim to broaden the skills and } \\
\text { competences of employees. }\end{array}$ & 4.17 & 1.192 & $28.59 \%$ \\
\hline Var.31”. & $\begin{array}{l}\text { There is great awareness and training in compliance with } \\
\text { occupational sa fety and health standards. }\end{array}$ & 4.59 & 0.789 & $17.19 \%$ \\
\hline Var.32ミ. & Employees integration activities are developed as a high priority. & 4.15 & 1.092 & $26.31 \%$ \\
\hline Var. $33 \equiv$ & $\begin{array}{l}\text { It can be consistently observed that the market has expanded } \\
\text { through new products developed in the company. }\end{array}$ & 3.88 & 1.224 & $31.55 \%$ \\
\hline Var.34a. & $\begin{array}{l}\text { There was a strong increase in revenues due to the decrease in } \\
\text { employee tumover. }\end{array}$ & 3.75 & 1.256 & $33.49 \%$ \\
\hline Var. $35 \geqq$ & $\begin{array}{l}\text { There was a strong increase of the company's competitiveness in } \\
\text { relation to the competitors, due to the above mentioned practices. }\end{array}$ & 3.94 & 1.109 & $28.15 \%$ \\
\hline \multicolumn{2}{|r|}{ Average of the Sustainability Practices Construct - Optimizers } & 3.5 & & \\
\hline
\end{tabular}

Source: Research data 
When considering the information in the table, it is possible to observe that the minimizing practices obtained a mean $(M=3.71)$ higher than that of an optimizing character $(M=3.5)$, which can be understood as a slope more accentuated toward the agreement between the two categorizations. This warns that enterprises demonstrate a more reactive than proactive intent in relation to sustainability practices. It is possible to infer that SMEs are still developing their most basic operational skills and that this development involves a greater maturation of them (AUTIO, et al., 2014). Within the minimization category, the variable that obtained the highest mean $(\mathrm{M}=4.81)$ of conformity was, close to total acceptance, the 17 th variable, which refers to the conformity of organizations regarding the environmental standardization. In this aspect this is an interesting perspective, since it may indicate an adaptation to a New context of an uncertainty generating area that, however, in the future has the capacity to provide competitive advantages (HENDERSON, 2015). It is also noticeable that there is a high cohesion of the given responses. Considering this, it is possible to observe that a strong tendency in the direction of normative isomorphism is present (DIMAGIO and POWELL, 1983), that is, the arguments developed by the authors, within the answers given in the sample, are shown to be valid. The second highest mean $(M=4.63)$ from the set of minimizing questions was the one that referred to the 16th variable: the disposal of waste production. In this question, the concern pointed out by the sample respondents was about the environmental dimension of sustainability, obtaining, as well, a relatively high average with propensity to total agreement. Regarding the dispersion, the answers can be considered of an average order. The third and fourth more relevant variables (20th and 16th) refer to the one posture focused on operational efficiency in a first step. This provides concerning the control of electricity and water usage in productive activities, also with very approximate means $(\mathrm{M}=4.5$ and 4.46 respectively), which reflects a consistent degree of agreement and also a common concern is SMEs linked to BOP (HALL, et al., 2014). In this regard, there was also a level of average dispersion of the responses provided in the sample. As to the minimizing category, it is possible to point out that of the 13 variables investigated, six reached means of agreement, that is, above the index 4, which corresponds to $46.15 \%$ of the set of questions. On the other hand, the question that obtained the lowest mean was the 26th $(\mathrm{M}=1.26)$, which indicates a total disagreement regarding the possibility of the increase of labor lawsuits arising from actions after the dismissal of employees. This demonstrates that managers have a robust and effective posture in order to avoid actions of this nature, managing in a strong way the question of Governance or the social dimension of sustainability, and the degree of cohesion of the answers provided within the sample was superior, indicating a low dispersion of responses. This indicates that there is a context that emphasizes the importance of avoiding problems of this nature, a position close to the perspective of Autio et al. (2014). It is important to highlight, in question 24, the importance of the workers' income to be above the average of the same sector $(\mathrm{M}=$ 2.84). This is a typical concern of SMEs, in which, there is a greater proximity between the organization and collaborators. This is also a characteristic pointed out by authors such as Cunningham et al. (1991) and Davidsson, et al. (2001). It can also be considered as an issue in emerging economies linked to the BOP, in which the topic of wage has a prominent importance (KISTRUCK, et al., 2015). Next, question 25, with a mean of $(M=4.15)$, indicates the high importance of the community, in which the cluster is inserted. The influence of this aspect in the company's decisions gains notable relevancy and also offers, in an almost unquestionable way, the proximate relation of SMEs to their environment, a phenomenon observed by other authors (BLUNDEL, et al. 2010; FERNHABER, et al. 2008; GASSE, et al. 1992; KAO, 1989; AUTIO, et al. 2014).

Regarding the optimizing category, the highest mean $(\mathrm{M}=4.59)$ refers to question 31 , which investigates awareness, training and obedience to meeting occupational safety and health standards, denoting a concern for improving the performance of employees (SILVESTRE et al., 2014). In this question, there is also a broad cohesion of the answers which may again mean an intense approximation to normative isomorphism (DIMAGIO; POWELL, 1983). The group mean $(\mathrm{M}=3.50)$ of the optimizing variables was right in the center, indicating a certain uniformity of behavior among the companies, however, it is not possible to indicate a trend, although $42.86 \%$ of the answers provided in the sample reached an agreement, which is a common perception in the textile industry, according to Gîrneatã (2013). In variables 33 and 34, performace is also one of the highlighted aspects, taking into account the expansion of the market and the growth of revenues, positive means indicate the improvement of 
SMEs organized in clusters, increasing competitiveness and activating the local community, bringing countless benefits identified to the BOP and necessary to the emerging economies (McCANN, et al. 2002; FOLTA, et al. 2006; PLA-BARBER, et al. 2009; ZHAO, et al. 2002). It can also be interpreted, based on this information, that the organizations are stagnant in relation to more proactive positionings, which is a perspective of not amplifying the actions beyond what the regulation requires. However, the relative position of the cluster in the competitive context ( 2 nd largest production center) of the garment industry offers stronger attributes in opposition to this interpretation.

\section{Categorization of companies according to Sustainability Practices Profile}

Considering the use of the cluster analysis carried out using the hierarchical Cluster Analysis technique of the SPSS software, it was possible to establish the organizations' profiles referring to sustainability practices. It is a non-hierarchical clustering method called K-means clustering, where it was previously defined that the number of clusters should be equal to four. The organizations were classified by virtue of their positions and degrees of agreement in relation to sustainability practices. All the companies in the sample were scrutinized.

Considering the cluster analysis of the sample organizations' profile classified according to their attitudes and evaluated decisions, in relation to sustainability practices and innovation strategies, it was possible to verify in the comparison of the constructs' profiles, that the companies that are at the same time strongly optimizing (considering sustainability practices) and complete (favoring innovation strategies) correspond to $34.82 \%$, which cannot be evaluated as a low number due to the contemporary demands and the size of the enterprises. On the other hand, companies that are both very weak (in sustainability practices) and beginners (in innovation strategies) are only 4 or $3.57 \%$ of the sample investigated, which can be considered as a positive fact, because of its small and almost irrelevant significance. Figure 2 summarizes the information pointing out inclinations and the different compliances to sustainability practices. It should be taken into consideration that sustainability practices are still in consolidation and the information about them is still confusing and dispersed even in the business environment.

Figure 2: Cluster analysis result

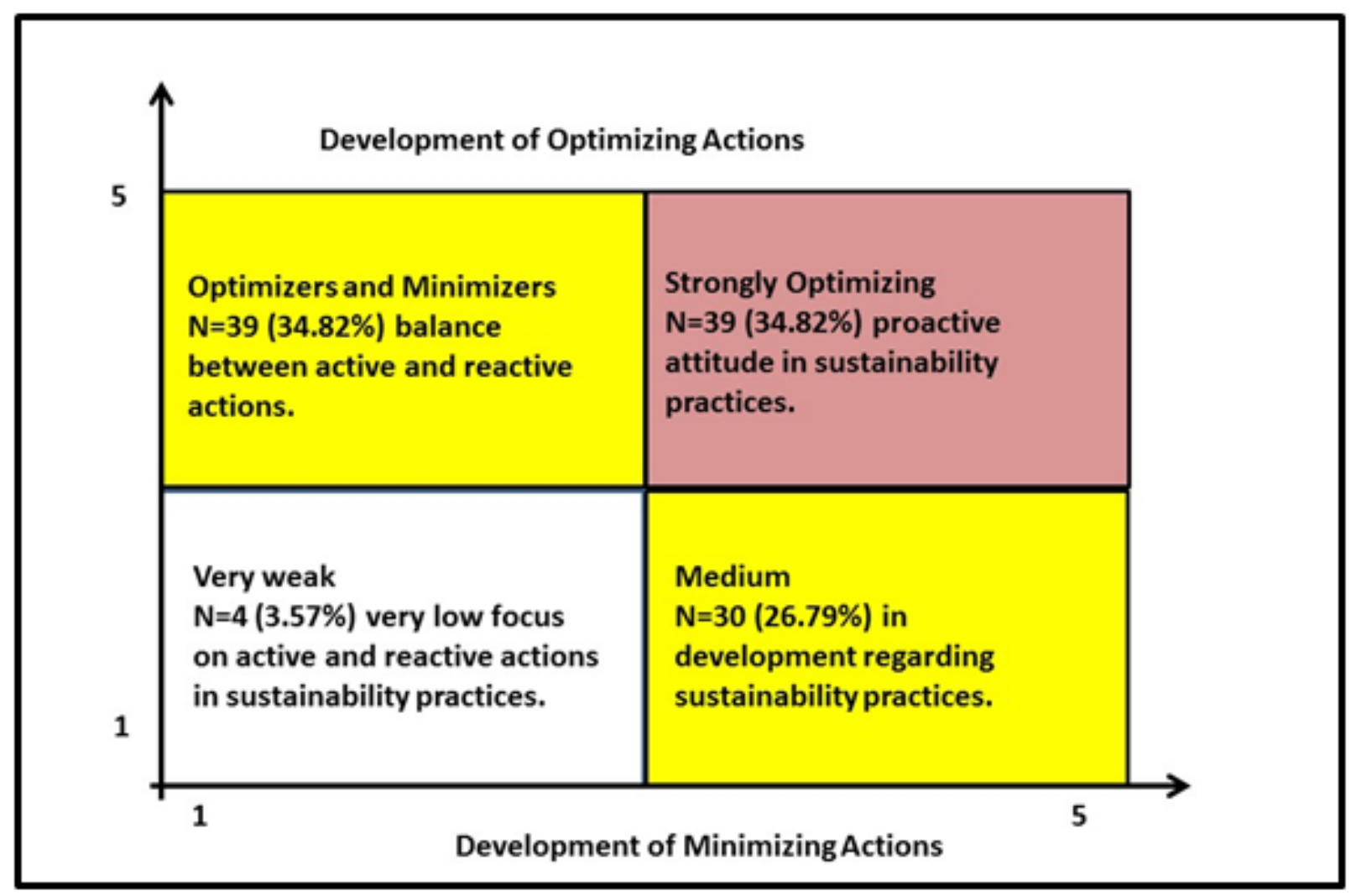

Source: Processing of research data 
These strongly optimizing aspects of sustainable practices, indicate that there is a clear positive trend, considering that most researched organizations are SMEs, which also influence the BOP economy. Usually these positions in companies also indicate that there is a long-term concern, taking into account that there will be changes in the operating environment, seeking with these operational improvements to be able to serve different niches. This is a strategic concern (HENDERSON, 2015).

\section{Verification of organizational performance differences in relation to innovation strategies and sustainability practices}

Within the ANOVA research to identify whether or not there is a difference in the propensity to balance the size (number of employees) in the three dimensions, according to the related characteristics, there are innovation strategies and sustainability practices categorized as minimizers and optimizers, as shown in Table 5. Variance analysis consists of a statistical technique intended to verify if the samples of three or more groups are derived from populations with equal means (HAIR et al., 2005a).

Table 5: ANOVA for balancing innovation strategies, sustainability practices and size

\begin{tabular}{|c|c|c|c|c|c|c|}
\hline \multicolumn{7}{|c|}{ AMPLITUDE } \\
\hline & & Sum of Squares & $\mathrm{df}$ & Mean Square & $\mathrm{F}$ & Sig. \\
\hline \multirow{3}{*}{ Strategy } & Between Groups & 1.16 & 2 & 0.58 & 1.069 & 0.347 \\
\hline & Within Groups & 59.176 & 109 & 0.543 & & \\
\hline & Total & 60.337 & 111 & & & \\
\hline \multirow{3}{*}{$\begin{array}{l}\text { Minimizers } \\
\text { Frequency }\end{array}$} & Between Groups & 1.369 & 2 & 0.684 & 2.869 & 0.061 \\
\hline & Within Groups & 25.993 & 109 & 0.238 & & \\
\hline & Total & 27.361 & 111 & & & \\
\hline \multirow{3}{*}{$\begin{array}{l}\text { Optimizers } \\
\text { Frequency }\end{array}$} & Between Groups & 2.198 & 2 & 1.099 & 1.645 & 0.198 \\
\hline & Within Groups & 72.818 & 109 & 0.868 & & \\
\hline & Total & 75.016 & 111 & & & \\
\hline
\end{tabular}

Source: SPSS output data

Through ANOVA, it was verified that there is no difference between the groups, in which the sizes of the innovation strategies are involuntarily equivalent to the company's size: micro, small, medium or large. It is an aspect to be emphasized, in table 6, how companies are much closer than the differences pointed out in their acting structures.

Table 6: ANOVA Tukey test Strategies

\begin{tabular}{|l|l|l|}
\hline & \multirow{2}{*}{ Company size } & Subset for alpha $=0.05$ \\
\cline { 3 - 3 } & $\mathrm{N}$ & 1 \\
\hline Medium and Large & 11 & 3.0056 \\
Small & 41 & 3.1951 \\
Micro & 59 & 3.3243 \\
Significance & & .295 \\
\hline
\end{tabular}

Source: SPSS output data 
Based on the results obtained and analyzed, it is possible to conclude that size (considering number of employees and revenue) does not interfere in the relationship between the categorized innovation strategies and sustainability practices. It may be considered that these different dimensions are more or less balanced regardless of the characteristics leaning to being minimizers or optimizers.

\section{DATA ANALYSIS AND PRESENTATION}

Based on studies on sustainability practices, there are several theoretical currents that seek to investigate the reactions of organizations to adapt to the dimensions of sustainability (GARUD et al., 2012; FURNALETTO et al., 2011; BARBIERI, et al. 2009). Inserted in this context, enterprises, especially those in clusters, need to develop innovation strategies that provide alternative behavior and performance alternatives that society more strongly demands as it develops (AUTIO et al., 2014; HANSEN, et al. 2011). One of the consequences and gaps pointed out by the study is that SMEs working in BPO economies strengthen each other when they organize themselves in clusters, especially regarding their Sustainability Practices in relation to Innovation Strategies, partially confirming studies such as that of Kistruck, et al. (2015).

There is a high probability that these innovation strategies imply initiatives of sustainability practices that are reflected in a strengthening in the conditions of the competition from the researched cluster's companies. In this scenario, aiming to broaden the frontier of knowledge on the themes of innovation strategies and sustainability practices, the present study proved and investigated the relationship between sustainability practices and innovation strategies in organizations of a cluster, linked to clothing, in the city of Cianorte, state of Paraná, Brazil.

While adopting and employing scales used to measure companies' sustainability practices (GRI, 2006), it was noticed that the reality of SMEs is not considered in its specificities in different situations (HALL et al., 2014; GÎRNEAŢĂ, 2013). Counting on adjustments, there are several raised scales (VELEVA, et al., 2001) which reflect similar situations to the context of the organizations at the bottom of the pyramid (BOP). Thus confirming the proposition of other studies of this nature (SILVESTRE et al,2013; AUTIO et al., 2014; KISTRUCK, et al., 2015). It is possible to affirm the existence of the relationship between these constructs studied from the score conferred by the owners, managers and people responsible for the organizations participating in the research, about the level with which their companies develop actions that demonstrate sustainability practices unfold in innovation strategies (HENDERSON, 2015), generating benefits to SMEs in a BOP economy.

It was possible to notice, through the information acquired by the means, that sustainability practices $(M=3.82)$ enjoy greater attention than innovation strategies $(M=3.24)$ by sample respondents. This indicates that the activities related to sustainability practices, in their two categories, strongly tend to a greater agreement, which will provide conditions of progress to the Cianorte cluster.

In spite of having achieved its goal of investigating the relationship between sustainability practices and innovation strategies in a cluster within a BOP economy, the study has, as a limitation, the impossibility of generalizing its statistical results, because it was based on data obtained from a single cluster and by means of a non-probabilistic sample. Thus, it is suggested that the present research be complemented by means of surveys of statistically significant samples, observing other clusters, which will allow the findings to be compared and become generalizable. 


\section{REFERENCES}

ARUNDEL, A.; KEMP, R. (2009). Measuring eco-innovation. UNU - MERIT Working Paper Series.

ATLAS TI. (2012) versão 6.0. Disponível em: http://www.atlasti.com>. Acesso em:24-05-2012. [S.1.]: [s.n.].

AUTIO, E.; KENNEY, M.; MUSTAR, P.; SIEGEL, D.; WRIGHT, M. (2014) Entrepreneurial innovation: The importance of context. v.43. Research Policy, 1097-1108

BARBIERI, J. C.; CAJAZEIRA, J. E. R. (2009). Responsabilidade Social Empresarial e Empresa Sustentável - da teoria à prática. São Paulo: Saraiva.

BARBIERI, J. C.; VASCONCELOS, I. F. G.; ANDREASSI, T.; VASCONCELOS F. C. (2010). Inovação e Sustentabilidade: novos modelos e proposições. Revista de Administração de Empresas. Rio de Janeiro: FGV. 2010, 146-154.

BARDIN, L. (2002). Análise de Conteúdo. Lisboa: Edições 70.

BLACKBURN, W. R. (2007). The Suatainability Handbook: The Complete Management Guide to Achieving Social, Economic and Environmental Responsability. Washington, DC: ELI Press.

BLUNDEL, R.K.; SPENCE, L.J.; ZERBINATI, S. (2010). Entrepreneurial social responsibity scoping the territory. In L.J Spence and M. Painter-Morland (eds) Ethics in small and medium sized enterprises a global commentary. Dordrecht; Springer.

BONN, I.; FISCHER, J. (2011). Sustainability: the missing ingredient in strategy. Vol. 32, iss: 1. [S.1.]: Journal of Business Strategy, 5-14.

BOS-BROUWERS, H. E. J. (2009). Corporate sustainability and innovation in SMEs: evidence of themes and activities in practice. [S.1.]: Business Strategy and the Environment.

BREWER, J.; HUNTER, A. (2006). Foundations of Multimethod Research: synthesizing styles. [S.1.]: Thousand OAKS: Sage.

BROWN, P.; BELL, J. (2001). Industrial clusters and small firm internationalisation. In J. H. Taggart, M. Berry, \& M. McDermott (Eds.), Multinationals in a new era (pp.10-26). New York: Palgrave.

BURGELMAN, R. A.; CHRISTENSEN, C. M.; WHEELWRIGHT, S. (2008). Strategic Management of technology and inovation. 5a.,ed. São Paulo: Mcgraw-Hill.

CAMPBELL, J. (2007). Why would corporations behave in socially responsible ways? An institucional of corporate social responsibility. Academy of Management Review, 32 (3). NY: [s.n.], 646-967.

CARVALHO, A. P.; BARBIERI, J. C. (2010). Innovation for Sustainability: overcoming the productivity of the sugar-and-ethanol industry's conventional system. V.5, N.4. Santiago: Journal of Technology Management \& Innovation, 83-94.

CASSIOLATO, J. E.; LASTRES, H. M. M. (2005). Innovation systems and local productive arrangements: new strategies to promote the generation, acquisition and difuffusion of knowledge. v.7, n.2 - a special issue of Inovation:Management, Policy \& Practice. [S.1.]: Inovation and Economic Development. 
CASSIOLATO, J. E.; SZAPIRO, M. (2003). Arranjos e sistemas produtivos locais no Brasil.. Rio de Janeiro: REDESIST.

CHESBROUGH, H. (2006). Open Innovation: A New Paradigm for Understanding Industrial Innovation. Open Innovation: A New Paradigm for Understanding Industrial Innovation. Oxford: Oxford University Press.

CLARO, P. D. O.; AMANCIO, R.; CLARO, D. P. (2008). Entendendo o conceito de sustentabilidade nas organizações. RAUSP. Vol.43, n.4. São Paulo: Revista de Administração da Universidade de São Paulo, 289-300.

COLLIS, J.; HUSSEY, R. (2005). Pesquisa em administração: um guia prático para alunos de graduação e pós-graduação. Trad. Lucia Simonini. 2a. ed. Porto Alegre: Bookman.

CRESWELL, J. W. (2010). Projeto de Pesquisa - métodos qualitativo, quantitativo e misto. 3 ed. Porto Alegre: Bookman/ARTMED - SAGE.

CUNNINGHAM, J.B. ; LISCHERON, J. (1991). Defining Entreneurship. Journal Small Business Management: v.29, 1; jan. ABI/INFORM Global p.45

DAVIDSSON, P.; WIKLUND, J. (2001). Levels of analysis in entrepreneurship for the future. V. 25, N. 4. Entrepreneurship Theory \& Practice, 81-100.

DiMAGIO, P. J.; POWELL, W. W. (1983). The iron cage evisited: institutional isomorphism and collective rationality in organization fields. American Sociological Rewiew, v. 48, n. 2, 147-160.

DYLLICK, T.; HOCKERTS, K. (2002). Beyond the business case for corporate Sustainability. Business Strategy and the Environment v.11. Paris: INSEAD, 130-141.

ELKINGTON, J. (1999). Cannibals with forks: the triple bottom line of 21 st century business. Oxford: Capstone Publishing Limited.

FEITOSA, M. G. G.; SILVA, F. F.; AGUIAR, V. D. S. M. (2012). Uma Reflexão sobre as Relações de Parceria no APL de Confecções do Agreste. V.13, N. 4. São Paulo: RAM - Revista Adm. Mackenzie. Jul./Ago, 206-235.

FERNHABER, S. A. ; GILBERT, B. A. ;McDOUGALL, P. P. (2008). International entrepreneurship and geographic location: An empirical examination of new venture internationalization. Journal of International Business Studies, v. 39, 267-290

FIELD, A. (2009). Descobrindo a estatística usando o SPSS. 2 ed. Trad. Lori Viali. Porto Alegre: Artmed.

FOLTA, T. B.; COOPER, A. ;BAIK, Y. (2006). Geographic cluster size and firm performance. Journal of Business Venturing, v.21, n.2, 217-242

FUNDEANU, D. D.; BADELE, C.S. (2014). The impact of regional innovative clusters on competitiveness. Procedia - Social and Behavioral Sciences - v.124, 405 - 414.

FURLANETTO, E. L.; CANDIDO, G. A.; MARTIN, M. F. (2011). Sustentabilidade em Arranjos Produtivos Locais: uma proposta metodológica de Análise. v.1, n.9. [S.1.]: PROPAD - Revista Eletrônica de Gestão Organizacional, 195-225. 
GASSE, Y.; CARRIER, C. (1992). Gérer la croissance de sa PME. Les éditions de l'entrepreneur. Montréal: [s.n.].

GARONE, L.F.; MAFFIOLI, A.; NEGRI, J.A.; RODRIGUEZ, C.M.;VAZQUES-BARE, G. (2015). Cluster development policy, SME's performance, and spillovers: evidence from Brazil. v.44. Springer Science + Business - Small Bus Econ. New York, 925-948

GARUD, R.; GEHMAN, J. (2012). Metatheoretical perspectives on sustainability journeys: Evolutionary, relational and durational. v. 41: Research Policy, 980-995

GÎRNEAŢĂ, A. (2013). The Importance of Clusters in the Development of the textile and clothing industry. Network Intelligence Studies - v. I, n. 2, Doctoral School of Management, The Bucharest Academy of Economic Studies, Romania, 83-89

GRI. GLOBAL REPORTING INITIATIVE. (2006). Disponível em. Acesso em: 10 set. 2011. [S.1.]: [s.n.].

HAIR JR., J. F. et al. (2005A) Fundamentos de métodos de pesquisa em Administração. Tradução Lene Belon Ribeiro. Porto Alegre: Bookman.

HAIR JR., J. F. et al. (2005B). Análise multivariada de dados. 5a. ed. Tradução Adonia Sant'Anna e Anselmo Chaves Neto. Porto Alegre: Bookman.

HAIR, J. F. et al. (1998). Multivariate data analysis. Upper Sadle River: Prentice Hall.

HALL, J. ; MATOS, S. V.; MARTIN, M.J.C. (2014). - Innovation and entrepreneurial dynamics in the Base of the Pyramid - v.34, Technovation, 284-294

HAMEL, G.; PRAHALAD, C. K. (1995). Competindo pelo Futuro. 9 ed. São Paulo: Campus.

HANSEN, E. G.; GROSSE-DUNKER, F.; REICHWALD, R. (2009). Sustainability Innovation Cube - A framework to Evaluate Sustentainability of product Innovations. XX ISPIM Conference. Vienna: [s.n.].

HANSEN, E. G.; BULLINGER, A. C.; REICHWALD, R. (2011). Innovation Contests for SustainabilityOriented Product Innovation Findings from a Worldwide Shoe Innovation Contest. Scharnhorststr. 1 / D-21335 Lüneburg. Lüneburg: Centrum für Nachhaltigkeitsmanagement (CNM) - Leuphana Universität.

HENDERSON, R. (2015). Making the Business Case for Environmental Sustainability. Working Paper 15-068. Harvard Business School, February 19.

HILKE, E.; BOS-BROUWERS, J. (2010). Corporate Sustainability and Innovation in SMEs: Evidence of Themes and Activities in Practice. v.19. n.7 [S.1.]: Business Strategy and the Environment, 417-435.

HUANG, J. Y.; LEE, G. G.; CHOU, T. C. (2010). Imitative innovation strategies: Understanding resource management of competent followers. v.48, n.6. Taiwan: Management Decision, 952-975.

IPIRANGA, A. S. R. (2006). Os arranjos e sistemas produtivos territoriais entre aprendizagem, inovação e cultura. In: Encontro da Associação Nacional de Pós-Graduação e Pesquisa em Administração ENAPAD, 30. Salvador: Anais. p. 1 CD-ROOM. 
JAMALI, D. (2006). Insights into the triple bottom line integration from a learning organization perspective. Business Process management Journal, v.12, n.6. New York:, 809-821.

JENSEN, M. B.(2004). Codification and modes of innovation. In: Druid's Summer Conference on Industrial dynamics, Innovation and Development, 2004. Elsinore: [s.n.].

JOHNSON, M. P.; SCHALTEGGER, S. (2015). Two Decades of Sustainability Management Tools for SMEs: How Far Have We Come? v. 54, n. 2. Journal of Small Business Management, 481-505.

KAO, R.W.Y. (1989). Entrepreneurship and Enterprise development. Toronto: holt, Rinehart and Winston of Canada, Limited.

KISTRUC, G.M; WEBB, J. W.; SUTTER, C. J.; BAILEY, A. V.G. (2015). The double-edged sword of legitimacy in base-of-the-pyramid markets. v.30 - Journal of Business Venturing, 436-451

KNEIPP, J. M. et al. (2011). Gestão da Inovação para o Desenvolvimento Sustentável: comportamento e reflexões sobre a Indústria Química. v.8, n.4. São Paulo: Revista de Administração e Inovação, 88116.

KRUGLIANSKAS, I. (1996). Tornando a pequena e a média empresa competitiva. São Paulo: Instituto de Estudos gerenciais e Editora.

KRUGLIANSKAS, I.; GOMES, C. M. (2009). A influencia do porte no comportamento inovador da empresa. v.6, n.2. São Paulo: Revista de Administração da Inovação - RAI, 05-27.

KÜHL, M. R. (2012). Interdependencia entre a colaboração para a Inovação e desempenho sustentável na Industria Brasileira de eletroeletronicos. Tese apresentada ao Programa de Pós-Graduação em Administração, área de concentração Estratégia e Organizações, do Setor de Ciências Sociais Aplicadas da Universidade Federal do Paraná. Curitiba: [s.n.]. p. 232.

LÉON-SORIANO, R.; MUNÕZ-TORRES, M. J.; CHALMETA-ROSALEN, R. (2010). Methodology for sustainability strategic planning and management. V.110, N:2. [S.1.]: INDUSTRIAL MANAGEMENT \& DATA SYSTEMS, 249-268.

LUNDVALL, B.; JOHNSON, B. (1994). The Learning Economy. V.1, No.2. [S.1.]: Journal of Industry Studies, 23-42.

MAÇANEIRO, M. B.; CUNHA, S. K. (2010). Eco-Inovação: um Quadro de Referência para Pesquisas Futuras. XXVI Simpósio de Gestão da inovação tecnológica. Vitória/ES: ANPAD - Associação Nacional de Pós-Graduação em Administração. p. Anais 1 CD.

MALHOTRA, N. K. (2001). Marketing research: an applied orientation. Upper Saddle River. [S.1.]: Prentice-Hall.

MAON, F.; LINDGREEN, A.; SWAEN, V. (2010). Organizational Stages and Cultural Phases: A Critical Review and a Consolidative Model of Corporate Social Responsibility Development. v.12 n.1. [S.1.]: International Journal of Management Reviews, 20-38.

MARINS, L. M.; ZAWISLAK, P. A. (2010). O desempenho inovativo de sete Firmas Brasileiras. In: XXXV ENCONTRO NACIONAL DOS PROGRAMAS DE PÓS-GRADUAÇÃO EM ADMINISTRAÇÃO. Rio de Janeiro: EnANPAD. p. Anais eletronico.

MATHAISEL, D. F. X.; COMM, C. L. (2011). A Strategy for Enterprise Sustainability. V.17 - Num.1. Cambridge: The Business Review. 
McCANN, P., ARITA, T. ; GORDON, I. R. (2002). Industrial clusters, transactions costs and the institutional determinants of MNE location behaviour. International Business Review, V.11, n.6, 647663

MDIC - MINISTÉRIO DO DESENVOLVIMENTO DA INDÚSTRIA E DO COMÉRCIO EXTERIOR. (2012). Plano de Ações do setor de Indústrias de Transformação. http://www.desenvolvimento.gov.br/ sitio/ - acesso em, 14-12-2012. Brasília: [s.n.].

MENDONÇA, F. M. et al. (2012). Condicionantes territoriais para a formação, desenvolvimento e estruturação de Arranjos Produtivos Locais. v.9, n.3. São Paulo: RAI - Revista de Administração e Inovação. jul/set., 231-256.

MILANEZ, B.; OLIVEIRA, A.P. (2013). Innovation for sustainable development in artisanal mining: Advances in a cluster of opal mining in Brazil. v.38, Resources Policy, 427-434.

OCDE - ORGANIZAÇÃO PARA COOPERAÇÃO E DESENVOLVIMENTO ECONOMICO. (2007). Reviews of Regional Innovation Competitive Regional Clusters. NATIONAL POLICY APPROACHES. [S.1.]: [s.n.].

OLIVEIRA, M. F.; TORKOMIAN, A. L. V. (2009). Aprendizagem Inovação em Pequenas Empresas Inseridas em Aglomerações Produtivas. 5 ème colloque de l'IFBAE. Grenoble: [s.n.].

OSTER, G. (2010). Characteristics of emergent innovation. V.29, n:6. [S.1.]: Journal of Management Development, 565-574.

PADILHA, M. L. (2009). Indicadores de desenvolvimento sustentável para o setor têxtil. (Tese de Doutorado). Unidade Faculdade de Saúde Pública (FSP) - USP. São Paulo: [s.n.].

PETRINI, M.; POZZEBON, M. (2010). Integrating Sustainability into Business Practices: Learning from Brazilian Firms. v.7, n.4, art.3. Curitiba: Brasilian Administration Review, 362-378.

PLA-BARBER, J.; PUIG, F. (2009). Is the influence of the industrial district on international activities being eroded by globalization? Evidence from a traditional manufacturing industry. International Business Review, v.18, 435-445

PORTER, M. E.; KRAMER, M. R. (2006). Strategy and society: the link between competitive advantage and corporate social responsibility. 84. Boston: Harvard Business Review, 78-92.

QUANDT, C. O. (2012). Redes de cooperação e inovação localizada - estudo de caso de um arranjo produtivo local. v.9,n.1. São Paulo: RAI - Revista de Administração e Inovação. jan./mar., 141-166.

RENNIGS, K. (1998). Towards a Theory and Policy of Eco-Innovation - Neoclassical and (Co) Evolutionary Perspectives. Discussion Paper n. 98 - 24. [S.1.]: Mannheim, Centre for European Economic Research (ZEW).

SACHS, I. (1986). Ecodesenvolvimento: crescer sem destruir. São Paulo: Vértice.

SACHS, I.; VIEIRA, P. F. (2007). Rumo à ecosocioeconomia: teoria e prática do desenvolvimento. São Paulo : Cortez.

SANBERG, M. (1999). Lamarckian vs Darwinian evolution of IT in Swedish public and private organizations: some preliminary results from a web questionnaire survey. European Association for Evolutionary Political Economy (EAEPE) Conference. Prague: [s.n.]. 
SAVITZ, A. W.; WEBER, K. (2007). A Empresa sustentável - o verdadeiro sucesso é o lucro com responsabilidade social e ambiental. São Paulo: Elsevier.

SCANDELARI, V. R. N.; CUNHA, J. C. (2013). Ambidestralidade e desempenho socioambiental de empresas do setor eletroeletrônico. v. 53, n.2. São Paulo: Revista de Administração de Empresas FGV, 183-198.

SEBRAE - SERVIÇO BRASILEIRO DE APOIO ÀS MICRO E PEQUENAS EMPRESAS. (2012). Critérios e conceitos para classificação de empresas.

SILVESTRE, B.S., SILVA NETO, R. (2014). Capability accumulation, innovation, and technology diffusion: Lessons from a Base of the Pyramid cluster - v.34. Technovation, 270- 283

SINVEST - SINDICATO DAS INDUSTRIAS DO VESTUÁRIO DE CIANORTE - PR. (2012). Dados do Quadro Associativo.

SOPAS, L. (2001). 'Born' exporting in regional clusters. In J. H. Taggart, M. Berry, \& M. McDermott (Eds.), Multinationals in a new era. New York, NY. Palgrave, 29-46.

STEAD, J. G.; STEAD, W. E.(2008). Sustainable strategic management: an evolutionary perspective. v.01, n.01. [S.1.]: Int. Journal Sustainable Strategic Management, 62-81.

STOIAN, M. C.; RIALP, J.; DIMITRATOS, P. P. (2017). SME Networks and International Performance: Unveiling the Significance of Foreign Market Entry Mode. v. 55, n. 1. Journal of Small Business Management, 128-148.

SHRIVASTAVA, P. (1995). Environmental technologies and competitive advantage. V.16. [S.1.]: Strategic Management Journal, 183-200.

VALE, G. V.; WILKINSON, J.; AMÂNCIO, R. (2008). Empreendedorismo, Inovação e Redes: uma nova abordagem. RAE-eletrônica, v.7, n.1, Art.7, jan./jun. São Paulo: FGV-EAESP/RAE-eletrônica.

VELEVA, V.; ELLENBECKER, M. (2001). Indicators of sustainable production: framework and methodology. v.9. [S.1.]: Journal of Cleaner Production, 519-549.

VIZEU, F.; MENEGHETTI, F. K.; SEIFERT, R. E. (2012). Por uma Crítica ao conceito de desenvolvimento sustentável. Cad. EBAPE BR - v. 10 , n.3, art.6. Rio de Janeiro: Editora FGV. set., 569-583.

WAN, D.; ONG, C. H.; LEE, F. (2005). Determinants of firm innovation in Singapore. V.25, n.3 - mar. [S.1.]: Technovation, 261-268.

ZHAO, H.; ZOU, S. (2002). The impact of industry concentration and firm location on export propensity and intensity: An empirical analysis of Chinese manufacturing firms. Journal of International Marketing, v.10, n.1, 52-71. 